\title{
How do primary and lower secondary teachers compare?
}

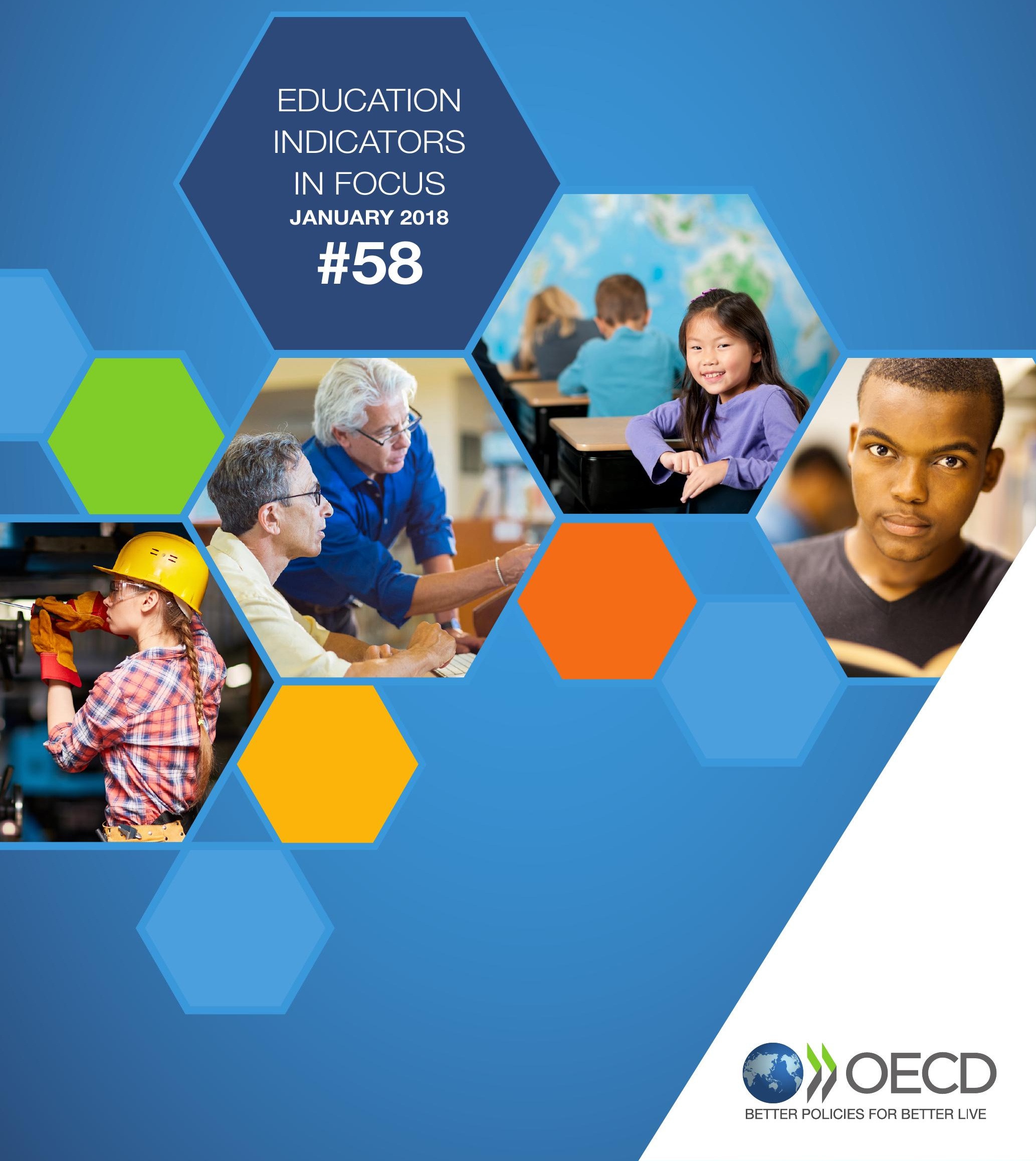




\section{How do primary and lower secondary teachers compare?}

- Primary and secondary teachers face different teaching and working conditions. A differentiated approach to teacher policy setting would help address effectively the specific challenges of each.

- While most OECD countries require both primary and secondary teachers to hold a similar tertiary qualification, a larger share of primary teachers' education is dedicated to pedagogical and practical training than lower secondary teachers. This may leave primary teachers insufficiently trained in the content they are expected to teach and lower secondary teachers underprepared for the daily practice of teaching.

- Countries face trade-offs when allocating resources to primary and lower secondary education. Since 2000 , average class sizes have fallen and statutory salaries have increased in most countries at both levels, though lower secondary teachers get paid more, teach less, and have larger classes on average than primary teachers. In general, countries that prioritise teaching and teachers over infrastructure and class size do perform better in PISA.

- The wide variations across OECD countries in the teaching hours per year and the low correlation with learning outcomes suggests there is little consensus on the most effective policies related to time spent teaching at both levels of education. However, schools could further benefit from developing ways to use teachers' time more efficiently so that they could devote more time to professional development, teaching-related work and learning.

Every year across OECD countries, around one million students graduate from programmes in the field of education, representing 10\% of all tertiary graduates (OECD, 2017a). Many of them will choose to embrace teaching as a vocation and profession. This brief focuses on primary and general lower secondary public school teachers, highlighting the differences in their teaching and working conditions and their implications for policy setting.

\section{A tertiary degree is a pre-requisite for entering the teaching profession}

The nature of entry requirements into teacher education programmes determines whether or not the teaching profession will attract qualified candidates from diverse backgrounds. Around twothirds of the 32 countries included in the analysis use selective entry criteria for teacher education in addition to diploma requirements, for prospective teachers for both primary or in lower secondary education (Table 1). Most commonly, candidates are selected based on their secondary school results, but in some cases an interview or a competitive examination is used (OECD, 2014a).

Once selected, the qualification awarded after successfully completing teacher education signals the level of knowledge and skills that new teachers have acquired. Most OECD countries currently require a similar tertiary qualification for prospective teachers in primary or lower secondary education, though the required degree itself may differ between countries. More than $40 \%$ of countries require primary and lower secondary teachers to have a Master's degree. In those countries, prospective teachers have more time to deepen their knowledge, and enhance their teaching skills, especially when pedagogical training and subject-matter training take place at the same time. However, some countries have differentiated their entry requirements by level of education taught. In Austria, Hungary, Luxembourg, Spain and Switzerland, primary teachers can start teaching with a bachelor's degree but a master's degree is needed for those wishing to teach in lower secondary education (Table 1; OECD, 2014a, 2017b). 
TABLE 1 / Entry requirements into teacher education and qualification needed to teach in primary and lower secondary education

\begin{tabular}{l|l|l|l}
\hline \multicolumn{2}{c|}{} & \multicolumn{2}{|c}{ Primary education teachers } \\
\cline { 3 - 4 } \multicolumn{2}{c|}{} & $\begin{array}{l}\text { Bachelor's degree or } \\
\text { equivalent required to } \\
\text { teach in public schools }\end{array}$ & $\begin{array}{l}\text { Master's degree or } \\
\text { equivalent required to } \\
\text { teach in public schools }\end{array}$ \\
\hline \multirow{4}{*}{$\begin{array}{l}\text { Lower secondary } \\
\text { education teachers }\end{array}$} & $\begin{array}{l}\text { Bachelor's degree or } \\
\text { equivalent required to } \\
\text { teach in public general } \\
\text { schools }\end{array}$ & $\begin{array}{l}\text { Australia, Chile, } \\
\text { Greece, Ireland, Israel, } \\
\text { Japan, Korea, Mexico, } \\
\text { Netherlands, Norway, } \\
\text { Scotland (UK), Turkey } \\
\text { and United States }\end{array}$ & \\
\cline { 2 - 4 } & $\begin{array}{l}\text { Master's degree or } \\
\text { equivalent required to } \\
\text { teach in public general } \\
\text { schools }\end{array}$ & $\begin{array}{l}\text { Austria, Hungary, } \\
\text { Luxembourg, Spain and } \\
\text { Switzerland }\end{array}$ & $\begin{array}{l}\text { Czech Republic, } \\
\text { England (UK), Estonia, } \\
\text { Finland, France, Germany, } \\
\text { Iceland, Italy, Poland, } \\
\text { Portugal, Slovak Republic, } \\
\text { Slovenia and Sweden }\end{array}$ \\
\hline
\end{tabular}

Note: Countries in bold apply selective criteria to enter teacher education.

Sources: OECD (2014a), "Indicator D6" Education at a Glance 2014: OECD Indicators, http://dx.doi.org/10.1787/eag-2014-en; OECD (2017b), Starting Strong V: Transitions from Early Childhood Education and Care to Primary Education, http://dx.doi. org/10.1787/9789264276253-en.

\section{The structure and content of teacher education programmes differs between primary and lower secondary level}

It is not so much the degree itself that matters than the skills being taught. Broadly speaking, there are two models of teacher education: concurrent, in which pedagogical and practical training are provided at the same time as general course components (e.g. subject and educational studies), and consecutive, in which teaching elements are learned after general ones.

Today, an increasing number of countries follow the concurrent model as it allows a more integrated learning experience. For instance, education programmes for prospective primary teachers in OECD countries are typically organised along concurrent lines. The situation is more mixed for lower secondary education, where countries may employ either model, or both together (EC/EACEA/ Eurydice, 2015; OECD, 2014a).

Another difference is the share of teacher education dedicated to pedagogical and practical training, which is generally higher for primary teachers than for lower secondary ones. In contrast, the time allocated to academic subjects is typically higher for lower secondary teachers, as they are often required to teach a more advanced curriculum in a selected number of subjects in some classes (OECD, 2014a). This partly explains why only $45 \%$ of lower secondary teachers across OECD countries feel "very well prepared" in the pedagogy of the subjects being taught while more than $60 \%$ of them feel "very well prepared" when asked the same question about the content of the subjects being taught (OECD, 2014b). This difference in the training curricula provided to primary and lower secondary teachers means countries need to focus more of the quality of professional development activities on pedagogical and classroom practices for lower secondary teachers, and on subject matter for primary teachers.

\section{Lower secondary school teachers are older than primary ones, but the under-representation of men is less pronounced in teaching at that level}

A balanced age distribution in the profession ensures continuity as staff and teachers approach retirement, helps bring fresh perspectives and innovative pedagogies into the classroom, and helps contain staff costs. On average across countries, lower secondary school teachers are older than primary teachers. The only exceptions to this pattern are Lithuania and the Slovak Republic, and to a lesser extent Brazil and France. Around one-third of primary and lower secondary teachers are 50 years old or over on average across OECD countries (OECD, 2017c). 
The gender distribution of teachers varies more widely between education levels. Having both male and female teachers is particularly beneficial to learning: it gives them a strong male role model in the classroom (Drudy, 2008). However, men are under-represented in the teaching profession, particularly in primary education, where they make up $17 \%$ of the teaching staff compared to $31 \%$ at lower secondary level (Figure 1). As the number of male teachers in primary and lower secondary schools continues to fall over the last decade (OECD, 2017a), gender inequality in the teaching profession is widely debated across OECD countries. The lack of competitiveness of teachers' salaries is one of the factors explaining this trend, although the attitudes of men related to social status and the difficulties faced by working in a field that is predominantly female (and in working in close proximity with young children for those in primary education) also play a role (Cushman, 2005).

\section{FIGURE 1 / Gender distribution of teachers (2015)}

Percentage of men among teaching staff, primary and lower secondary education

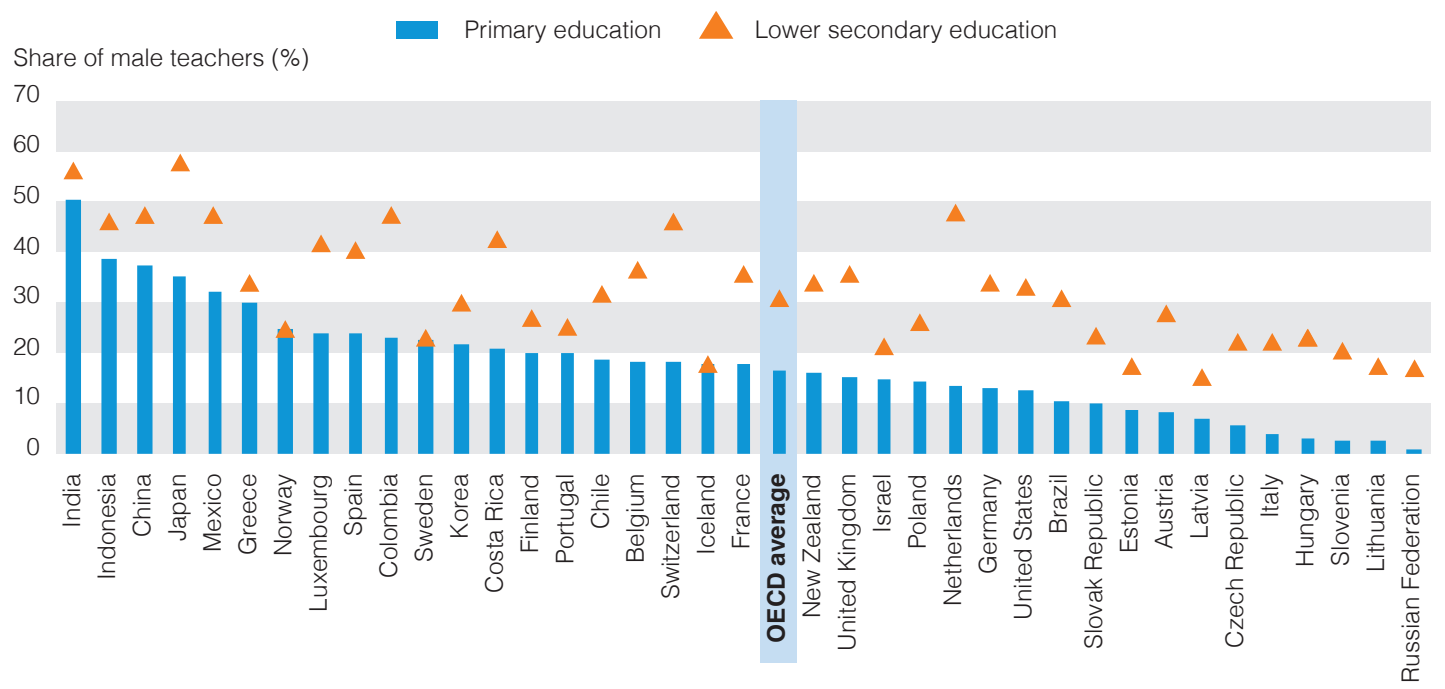

Countries are ranked in descending order of the share of male teachers in primary education.

Source: OECD (2017c), "Indicator D5" Education at a Glance 2017: OECD Indicators, http://dx.doi.org/10.1787/eag-2017-en.

FIGURE 2 / Statutory teachers' salaries (after 15 years of experience) relative to earnings for tertiary-educated workers (2015)

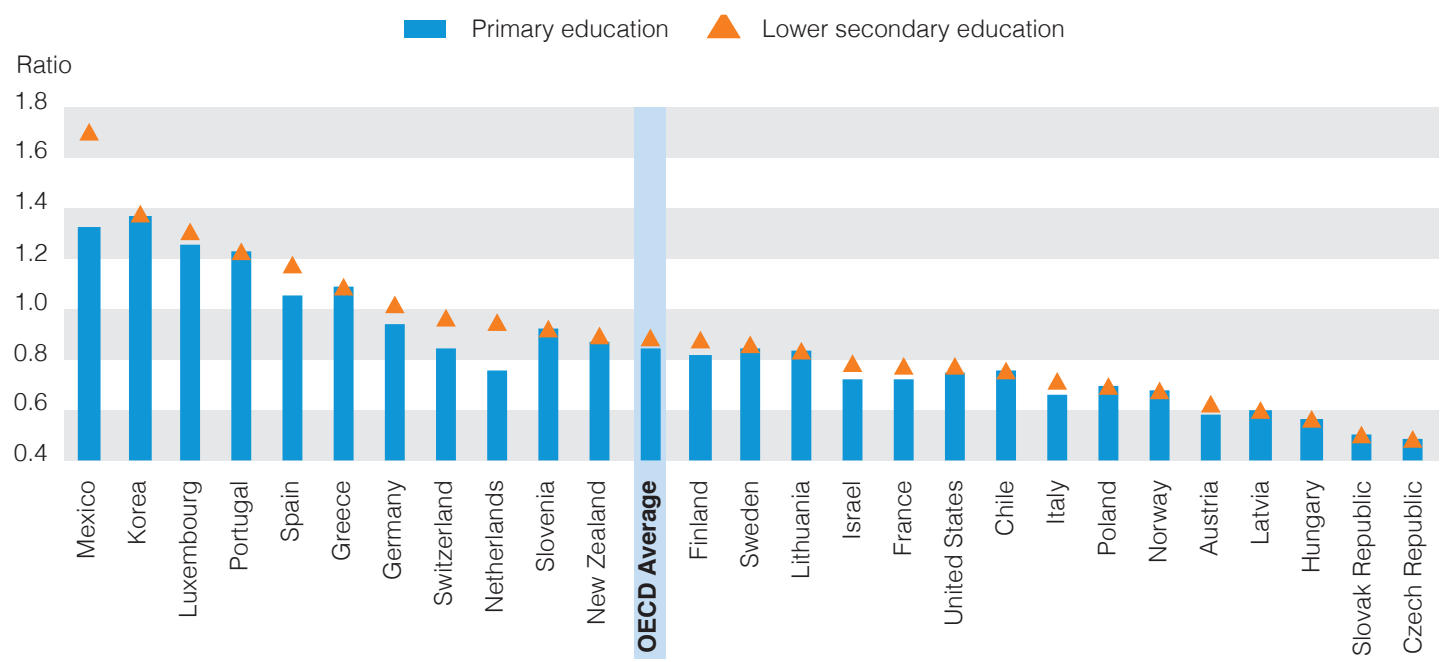

Note: This chart shows the ratios of salary in primary and lower secondary general education, using statutory salaries of teachers with 15 years of experience and typical qualifications (regardless of age) in public institutions relative to the earnings of full-time, full-year workers (25-64 year-olds) with tertiary education.

Countries are ranked in descending order of the ratio in lower secondary general education.

Source: OECD (2017c), "Table D3.2b" Education at a Glance 2017: OECD Indicators, http://dx.doi.org/10.1787/eag-2017-en. 


\section{Teachers' salaries are less attractive in primary education than in lower secondary education}

In less than half the countries with available data, there is very little difference between the statutory salaries of primary and lower secondary teachers with 15 years of experience. The largest differences in statutory salaries are found in Mexico, the Netherlands, Spain and Switzerland - four countries where the share of male teachers in lower secondary education is significantly higher than in primary education (Figures 1 and 2). On average, the statutory salaries of primary school teachers (aged 25-64) are $84 \%$ of the wages of all tertiary-educated workers, compared to $89 \%$ in lower secondary education. Between 2000 and 2015, teachers' statutory salaries increased in real terms in most countries. Interestingly, teachers are not better paid in countries requiring a master's degree, rather than a bachelor's, to enter the teaching profession (Table 1 and Figure 2). However, countries with a higher ratio of statutory teachers' salaries (after 15 years of experience) relative to the wages of all tertiaryeducated workers do tend to attract a larger share of men teaching at both levels (Figures 1 and 2).

\section{Teachers in lower secondary education spend $10 \%$ less time teaching than primary teachers, and their classrooms are slightly larger}

Good teaching conditions, such as a manageable workload and class size, may also play a role in attracting young people to teach and help retain effective teachers in the profession. There is little difference in the total number of statutory working hours between primary and lower secondary school teachers. There are important differences, however, in how they spend their time - and how much time is available for activities other than direct teaching (OECD, 2017c). On average, primary teachers are expected to spend 74 more hours per year in teaching. But there are large variations across countries. For example, in the Czech Republic, the Flemish community of Belgium, France and Turkey, primary school teachers have at least 30\% more annual teaching time than lower secondary school teachers (Figure 3).

The TIMSS 2015 study shows that primary and lower secondary teachers typically face more challenges in countries with the longest teaching hours (IEA, 2016). In addition, the large variations across OECD countries in the teaching hours per year and the low correlation with learning outcomes suggest there is little consensus on the most effective policies related to time spent teaching at both levels of education. However, schools could further benefit from developing ways to use teachers' time more efficiently so that they could devote more time to professional development, teaching-related work and learning.

FIGURE 3 / Teaching hours per year in primary and general lower secondary education (2015)

Net statutory contact time in public institutions

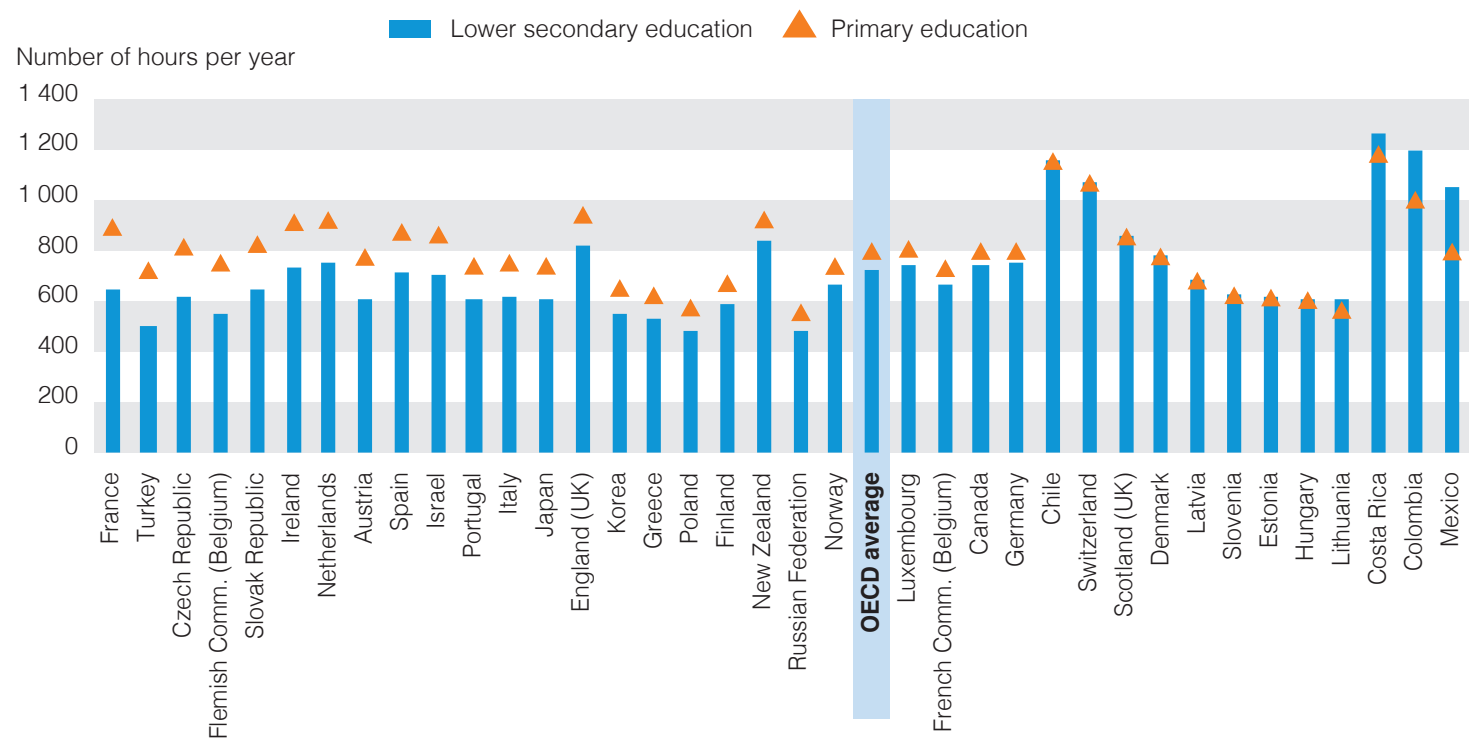

Countries are ranked in descending order of the difference between the number of teaching hours in primary and lower secondary education. Source: OECD (2017c), "Indicator D4" Education at a Glance 2017: OECD Indicators, http://dx.doi.org/10.1787/eag-2017-en. 
While teaching hours are shorter in lower secondary education in most countries, classes are on average larger. The average primary school class in OECD countries has 21 students, but this increases to 23 students in lower secondary education. Since 2000, these average class sizes have fallen for both levels. However, the impact of class size on education quality is a highly contested issue within the research. In general, countries that prioritise teaching and teachers over infrastructure and class size do perform better in PISA (OECD, 2016).

\section{The bottom line}

While policy debate is often focused on the whole teaching profession, primary and secondary teachers differ in more ways than one. While all countries require teachers to have at least a bachelor degree to enter the profession in primary or lower secondary education, the structure and content of the programmes vary and are less geared towards practice at secondary than primary level. Primary school teachers spend on average $10 \%$ more of their working time teaching, though their class size will be slightly smaller. Finally, primary teachers' salaries are less competitive than their lower secondary peers in more than half of the countries. Improving the attractiveness and effectiveness of the teaching profession can only be addressed by recognising these differences and adapting a differentiated policy to address the challenges of each.

\section{FOR MORE INFORMATION:}

Cushman, P. (2005), "Let's hear it from the males: Issues facing male primary school teachers", Teaching and Teacher Education, An International Journal of Research and Studies, Vol. 21/3, pp. 227-240.

Drudy, S. (2008), "Gender balance/gender bias: The teaching profession and the impact of feminisation", Gender and Education.

EC/EACEA/Eurydice (2015), The Teaching Profession in Europe: Practices, Perceptions, and Policies, Eurydice Report, Publications Office of the European Union, Luxembourg, http://eacea.ec.europa.eu/education/ eurydice/documents/thematic reports/184EN.pdf.

IEA (2016), "Download center", TIMSS 2015 website, International Association for the Evauation of Educational Achievement, http://timss2015.org/download-center/.

OECD (2017a), Online Education Database, OECD, www.oecd.org/education/database.htm.

OECD (2017b), Starting Strong V: Transitions from Early Childhood Education and Care to Primary Education, OECD Publishing, Paris, http://dx.doi.org/10.1787/9789264276253-en.

OECD (2017c), Education at a Glance 2017: OECD Indicators, OECD Publishing, Paris, http://dx.doi.org/10.1787/ eag-2017-en.

OECD (2016), PISA 2015 Results (Volume I): Excellence and Equity in Education, PISA, OECD Publishing, Paris, http://dx.doi.org/10.1787/9789264266490-en.

OECD (2014a), Education at a Glance 2014: OECD Indicators, OECD Publishing, Paris, http://dx.doi.org/10.1787/ eag-2014-en.

OECD (2014b), TALIS 2013 Results: An International Perspective on Teaching and Learning, OECD Publishing, Paris, http://dx.doi.org/10.1787/9789264196261-en.

\begin{tabular}{ll}
\hline VISIT & Www.oecd.org/education/education-at-a-glance-19991487.htm \\
& $\begin{array}{l}\text { Education Indicators in Focus (previous issues) } \\
\text { PISA in Focus } \\
\text { Teaching in Focus }\end{array}$ \\
\hline NEXT TOPIC & $\begin{array}{l}\text { How does participation in ECEC affect the participation of women in the labour } \\
\text { market? }\end{array}$ \\
\hline CONTACT: & $\begin{array}{l}\text { CoNic Charbonnier (eric.charbonnier@oecd.org) } \\
\text { ECD }\end{array}$ \\
\hline
\end{tabular}

Photo credit: (C) Christopher Futcher / iStock; @ Marc Romanelli / Gettyimages; @ michaeljung / Shutterstock; @ Pressmaster / Shutterstock This work is published under the responsibility of the Secretary-General of the OECD. The opinions expressed and arguments employed herein do not necessarily reflect the official views of OECD member countries.

This document, as well as any data and any map included herein, are without prejudice to the status of or sovereignty over any territory, to the delimitation of international frontiers and boundaries and to the name of any territory, city or area.

The statistical data for Israel are supplied by and are under the responsibility of the relevant Israeli authorities. The use of such data by the OECD is without prejudice to the status of the Golan Heights, East Jerusalem and Israeli settlements in the West Bank under the terms of international law. 